\title{
THE IMPACT OF SCHOOL LITERACY MOVEMENT (GSL) ON THE LITERACY ABILITY OF THE FIFTH GRADERS AT SD NEGERI GUNUNG SARI, RAPPOCINI DISTRICT, MAKASSAR CITY
}

\author{
Ahmad Syawaluddin ${ }^{1}{ }^{*}$, Nurhaedah $^{2}$ \\ 1 Fakultas Ilmu Pendidikan, UNM \\ 2 Fakultas Ilmu Pendidikan, UNM
}

\begin{abstract}
This research was aimed at knowing the impact of (GLS) on the students' literacy ability of the fifth graders at SD Negeri Gunung Sari I, Rappocini district, Makassar city in the school year 2016/2017. The research approach used a quantitative approach with Pre-experimental Research design. The sample was selected with purposive sampling by choosing class $V$ as experiment class with the total number of 66 students and those who were present were 50 students. The techniques of data collection used in this research were test and documentation. The data collected from the literacy ability test result were then analyzed using descriptive statistical analysis and inferential statistical analysis using sample t-test of Wilcoxon Test by using the test of two sides (two tailed test). To test the normality of the data distribution, Kolmogrov-Smirnov Normality Test was used with Asymp Sig. (2-Tailed) of 0.002 for pretest data and 0.003 for posttest data. Literacy ability on initial test (pretest) was in very satisfactory category with the mean of 83.99 and the literacy ability in the final test (posttest) was in very satisfactory category with the mean of 90.23. Hypothesis testing was done by using Wilcoxon Test Asymp Sig. (2-tailed) the value was $0.00<0.05$. The conclusion of research based on the result of analysis showed that there is an impact of school literacy movement (GLS) on students' literacy ability of fifth graders of SD Negeri Gunung Sari I in Rappocini disctrict, Makassar city.
\end{abstract}

\section{Keywords:}

GLS, reading

comprehension

\section{Introduction}

Education has an important role in the life of the nation and the state, that is to ensure the continuation of the life of the nation and its development. This is as what is stated in Act No 20 of 2003 on National Education System (2003:2) Article 1 that states that "Education is a conscious and planned endeavor to realize learning conditions and learning process in order the students actively develop their self potentiality to possess religious spiritual power, self control, personality, intelligence, noble character, and skills needed by the students themselves, the community, the nation, and the state." Education becomes a primary need that has to be acquired by everyone to be able to answer the challenges of the life in the future (Novitasari, 2017). The importance of the role of education requires the community members to always develop and improve as well as renew education in order to be useful for enhancing the quality of national education, so that it can create human resources that are expected and have national civilization that is dignified and intelligent.

Elementary school is the first formal education undergone by the student, and has a great contribution as the first foundation of knowledge for further education. At the elementary school level, five major subjects are taught, i.e, mathematics, science, social science, Indonesian and Civics and Pancasila education. In Indonesian subject the major activities are reading and writing. Today no days pass without reading and writing activities (Kurniawan, 2017). Reading is one of the most important efforts in the teaching and learning process. It is a very crucial step that determines the success or the lack of it of the teaching and learning process expected (Faradina, 2017). By reading we translate, interpret signs or symbols in the language that is understood by the reader. However, what is seen in the field is

* Corresponding author.

E-mail Addresses: unmsyawal@gmail.com (Ahmad Syawaluddin), nurhaedahrahman04@gmail.com (Nurhaedah) 
that the interest to read and write of Indonesians is still very low. This message can be quoted from the result of a research of Most Literate Nation in the World done by Central Connecticut State University (at http://www.edukasi.kompas.com) on March 2016 that states that Indonesia ranks 60 of 61 nations in in interest in reading and writing. The skill in reading and writing is called literacy. Literacy according to Kamus Besar Bahasa Indonesia means something related to reading and writing tradition.

Students' literacy skill is closely related to the demand on reading skill which ends in the ability to understand information analytically, critically, and reflectively in this $21^{\text {rst }}$. Literacy is very important for the students since the skill in literacy has an effect on their success in learning and life. Good literacy skill will help students in understanding oral, written and pictorial/ visual texts Literacy itself can be defined as literacy and writing ability. To encourage students to be literate can be done with various programs at school with its umbrella. The school programs which support the development of students who are literate are the major characteristic of a high quality school. These programs should not become spectacular activities, but should become programs that form the students' habit and culture in reading, writing and speaking.

The result of research published by Organisation for Economic Co-operation and Development (OECD) in Programme for International Student Assessment (PISA) 2012 shows that Indonesian students rank 64 of 65 countries by gaining the score of 396 using average reading score of 493 (OECD, 2014) in PISA 2015 shows that Indonesian students rank 64 of 70 nations by obtaining the score of 397 using the mean score for reading of 490 (OECD, 2016). Sixty five nations participated in PISA 2012 and 70 of them participated in PISA 2015. From the two results it can be said that educational practices done at schools have not yet shown the school function as an organization of learning that endeavors to make all of the members literate to support them as long life students.

The news published by Khalid (2016) states that USAID programs priorities have done early grade reading assessment of 15,941 students sampled in seven assisted provinces in Indonesia starting from 20012 - 2015. The seven provinces are Aceh, North Sumatra, Banten, West Java, Central Java, and South Sulawesi. The result of the study showed that many children sampled by the prioritas program can read well but do not understand the meaning of the text being read. Their understanding was still low below 80\%. According to Jamaruddin, Coordinator, USAID prioritas of South Sulawesi Province (Khalid, 2016) the results of the study need to be responded seriously by the local government and related stake holders and the ability to understand a text will influence the students' comprehension during learning. Students also have difficulties in developing other skills which are often acquired through reading.

Based on this consideration, the Ministry of Education and Culture developed School Literacy Movement (GSL) (reading for 15 minutes before a lesson starts) which involves all stakeholders in education, from the central government level, province, regency/ city to school In addition, external and public elements, i.e. , parents of the students, alumni, community members, businesses and industries als become important components in GSL.

The development of GSL based on the Regulation of the Minister of Education and Culture No.23 of 2015 on the Development of Character Article 1 letter 4, "Habituation is a series of activities done by students, teachers, and educators aimed at developing a good habit and educate the generation to be a generation with positive character". This is related to reading books outside of the lessons for 15 minutes before the class starts. According to Faizah, et al. (2016:2), "GLS is aimed at enhancing the capacity of the students and the school staff to become literate." The activity is an effort to develop the love for reading in the students and pleasurable experience and at the same time stimulating the imagination.

According to Abidin (2015:351), " this school program has become the key to the formation of a school with good character, that is a school which has the habit patterns that support students' success. In the future." In line with this, an effective teaching needs to pay attention to the need, interest, age, background, and environment of the students. Literacy teaching that is intended here is the reading culture or reading activities at school. Literacy teaching in United State Agency for International Development (USAID) Prioritas (2015:3), "literacy reading at elementary school is very important to support success in the students' academic achievement. "This statement is related to literacy competencies ( listening- speaking, reading- writing, arithmetics and considering, and observingdrawing) that are appropriate to be developed since elementary school, which is then followed up at a higher level to access information and knowledge. In addition, the students are able to differentiate useful from useless information. This is due to the fact that literacy directs an individual to the ability to understand messages which take various forms (oral, writing, visual).

USAID Prioritas (2015) describes the application of the activity of Silently Read (Hening Membaca) at SDN Cibabat Mandiri 4 Cimahi West Java during two semesters in the school year 20142015 with the result of increased interest in reading and literacy ability of the students. Besides, the demand for reading books at schools also grows. The result of a study by Kurniawati (2016) entitled Effort at the Realization of Literacy Literate Schools through Gelis Batuk. ( School Reading, Writing, 
Performing Literacy) is a program to enhance students' literacy ability. The result of the study showed that there is an increase in the students' literacy ability after the implementation of Gelis Batuk. A further research was done by Wulandari ( 2017) with the title The Implementation of School Literacy Movement at Elementary School at SD Islam Terpadu Lukman Hakim Al Internasional. The result described that ther is a reading program and the school policy that supports GLS, the supporting factors and the inhibiting factors in the implementation of GLS at SDIT Lukman Al Hakim Internasional.

The data that were collected through an observation at SD Gunung Sari I Rappocini District in Makassar City on January 18 and February 8,2017 showed that the implementation of GLS took the form of reading activity in 15 minutes before a lesson starts in the school. This was seen with the availability of a school program, school library, reading corner, and reading wheelbarrow that support the implementation of reading activity in 15 before a lesson starts by students and teachers. The 15 minute reading activity is part of the GLS habituation stage.

This study was aimed at 1) describing students' literacy ability before and after the implementation of GLS at SD Negeri Gunung Sari I Rappocini District in Makassar City in the school year 2016/2017. 2) finding out the impacts of school literacy movement ( reading activity for 15 minutes before a lesson starts) on the fifth graders' literacy ability at SD Negeri Gunung Sari I, Rappocini District, Makassar City in the school year 2016/2017.

\section{Method}

This study used one group pretest- posttest design. In this design, the sample was subjected to the treatment and was measured twice. The first measurement was done before the treatment and the second after the treatment (Sugiyono,2012). This design can be shown in the following figure.

$$
\begin{array}{ccc}
\text { Pre-test (01) } & \text { Treatment using KWL strategy technique in reading } \\
\text { lesson (X) } & \text { Post-test (O2) }
\end{array}
$$

The independent variable was school literacy movement (GLS). GLS is reading acttivity done by students and teachers before a lesson starts. The reading activity lasted for 15 minutes.

On the other hand, the dependent variable was the students' literacy ability, that is, the posttest scores obtained by the students after being given the treatment.

Literacy ability in GLS is the ability to read with the purpose of understanding the contents of the text according to the indicators in understanding a text and the ability to read aloud with the purpose of understanding the text according to the elements of the story read.

The instrument used in this study was in the form of comprehension questions given as posttest. The population in this study was the upper graders at SD Negeri Gunung Sari I, Rappocini District, Makassar City with the total number of 185 students. The sampling technique used was purposive sampling technique, that is the selection of sample based on a particular consideration. The consideration was that the suitability with the focus of GLS (Faizah, 2016). The sample was the fifth graders with the total number of 66 students. In this study the data were collected by doing three stages as illustrated below.:

\section{Peretest}

Pretest was done before treatment and was aimed at finding out reading ability before treatment

\section{Treatment}

Treatment took the form of reading for 15 minutes before a lesson starts in the experiment class.

3. Posttest

At this stage, the students were given a number of structured problems to compare ability to read after treatment.

The technique for data analysis used by the author was statistical technique, because this study was a quantitative research, so that there were two types of statistics used, i.e, 1) descriptive statistics to describe literacy ability obtained by the students of the experiment group. The ability to read was then compared by grouping them as follows.

Table Guideline for Categorization of Students' Literacy Ability \

\begin{tabular}{cc}
\hline $\begin{array}{c}\text { Score Interval } \\
(\mathbf{1 0 0 \% )}\end{array}$ & Category \\
\hline 80 and higher than 80 & Excellent \\
\hline $70-79$ & Very Good \\
\hline $60-69$ & Good \\
\hline
\end{tabular}




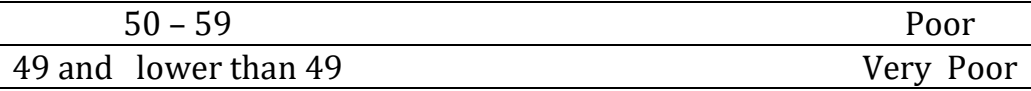

2) the study used inferential statistics to test the hypothesis by using t-test with different data.. Before hypothesis testing, normality testing was conducted with the aid of SPSS Statistics version 20.0.

\section{Results and Discussion}

This study analyzed the effect of school literacy movement ( reading activity for 15 minutes before a lesson starts) on the literacy ability of the fifth graders of SD Negeri Gunung Sari I, Rappocini District, Makassar City. This experimental study used Pre-experimental design with One Group PretestPosttest Design. This design was selected because the researcher would give treatment only to the experimental class.

The sample in this study consisted of 50 students. The experiment class was the class that was given the treatment in the form of school reading activity for 15 minutes before a lesson starts). In this study at SD Negeri Gunung Sari I in the fifth grade was selected as experiment class.

Reading activity for 15 minutes was done, i.e., reading aloud, in which before the study the author prepared listening material from a book in the class. The teacher read a short story to the students. The reading aloud activity lasted 15 minutes and could be given additional activity in the form of giving short questions to the students about the listening material. The 15 minute reading, could be followed with silent reading by the students and the teacher. In the silent reading, the book used was the one found in the classroom corner, reading wheelbarrow, or the library. In this study the reading material was in the form of sheet taken from a book from the classroom corner. In the reading aloud activity the author filled out a reading card and in the silent reading, the students filled out the reading card.

\section{Students' Literacy Ability}

Before giving the treatment to the experiment class, they were given the pretest first to obtain baseline data for the experiment class. After the pretest then they were given a treatment in the form of the 15 minute reading activity before a lesson started. After the treatment then they were given the posttest to find out the students' literacy ability after the treatment was given. Based on the descriptive analysis it was found out that the result of the pretest and the posttest in the students' literacy ability fell into very high category with the mean of 83.99 for the pretest and of 90.23 for the posttest.

Based on the descriptive analysis result it can be concluded that the students' reading ability of the experiment class fell into very high category after the treatment was given. This is seen from the means for the experiment class of 83.99 and 90.23, falling into very high category based on the categorization of literacy abilities. The literary ability with very high category describes that the literacy ability indicator has been reached. Literacy ability consists of the ability to read silently and aloud. THe indicator in silent reading about the comprehension in reading consists of literal understanding, reorganizing, inferential understanding, evaluating as adopted from Yonantin (2014). The indicators are in line with the focus of GLS at the habituation stage and silent reading (Dalman, 2013). The indicators for reading aloud to understand the content of the text) include characters and characterization, setting, theme, message adopted from the result of the study done by Nurcahyo Nurcahyo (2014). The indicators for reading aloud are suitable with the purpose of reading aloud (Dalman, 2013), i.e, to understand the text, including the elements of the story.

\section{Impact of GLS on Students' Literacy Ability}

Based on the t-test result of the experiment class, it is found out that there is a difference in literary ability of the students viewed from the literacy ability before and after treatment in the form of GLS ( the 15 minute reading activity) in the experiment class.

If looked at from the difference in literacy ability before and after reading activity, it is found out that there is an increase in literacy ability in the experiment class, seen from the value of Asymp Sig. (2tailed) which is smaller than yang 0.05 and the difference in mean in the result of pretest and posttest in the experiment class. Based on this result, it can be concluded that there is a significant difference in literacy ability before and after the treatment in the form of GLS ( the 15 minute reading ability before a lesson starts).

The result of this study is in agreement with what is stated by Faizah, et al (2016:2), "GLS is aimed at improving the capacity of the members of the school community and environment to become literate"). The result of this study parallels to the result of the study done by (2016) entitled Upaya Mewujudkan Sekolah Melek Literasi Melalui Gelis Batuk. Gelis Batuk (Gerakan Literasi Sekolah Baca Tulis Karya) which was a program to improve literacy ability and reading ability of the students. The result shows that there is an increase in the students' literacy ability after Gelis Batuk was implemented.. 
Based on the result it is clear that the more often GLS is implemented, the better the students' literacy ability. Based on the discussion above, it is concluded that there is an effect of school literacy movement ( the 15 minute reading activity before a lesson starts) on the fifth graders' literacy ability at SD Negeri Gunung Sari I in Rappocini District, Makassar City.

\section{Conclusion and Suggestion}

Based on the result of this study some conclusions can be made which include: 1) Students' literacy ability in the experiment class was in the very high category. This finding can be seen from the means in the pretest and posttest The mean in the pretest was 83.99 and the mean in the posttest was 90.23, 2) School Literacy Movement (GLS) had an effect on the elementary school students' literacy ability at SD Negeri Gunung Sari I Rappocini District, Makassar City. This can be seen from the difference in reading ability before and after the implementation of GLS ( the 15 minute reading activity before a lesson starts) with the value of Asymp Sig. (2-tailed) of the scores of the pretest and the posttest smaller than 0.05, which means they are significantly different.

The suggestion for the school principal is to make this study become a motivation in improving school literacy movement stage done with the stages of development and teaching: 1) The teacher can improve the process of the implementation of school literacy movement at the habituation stage, particularly in the implementation of the 15 minute reading activity before a lesson starts, 2) It would be better if the students try to improve their reading interest and reading ability. Besides, the students should be able to improve interactions with other students first, 3) For further researchers, this study could be used as reference.

\section{References}

Abidin, Yunus. 2015. Pembelajaran Multiliterasi Sebuah Jawaban atas Tantangan Pendidikan Abad Ke-21 dalam Konteks Keindonesiaan. Bandung: PT Refika Aditama.

Bundu, Patta. 2016. Asesmen Pembelajaran Untuk Guru dan Calon Guru Sekolah Dasar. Padang: Hayfa Press.

Buku Saku Pegangan Gerakan Literasi Sekolah. Modul. Jakarta: Kemedikbud.

Dalman. 2013. Keterampilan Membaca. Jakarta: PT RajaGrafindo Persada.

Faizah, D. U, Sufyandi, S, Anggraini, L, Waluyo, Dewayani, S, Muldian, W, Roosaria, D. R. 2016. Panduan Gerakan Literasi di Sekolah Dasar. Jakarta: Direktorat Jenderal Pendidikan Dasar dan Menengah Kementerian Pendidikan dan Kebudayaan.

Faradina, Nindya . 2017. Pengaruh Program Gerakan Literasi Sekolah Terhadap Minat Baca Siswa Di Sd Islam Terpadu Muhammadiyah An-Najah Jatinom Klaten. Jurnal Hanata Widya Volume 6 Nomor 8.

Hakim, Abdullah. 2014. Peningkatan Kemampuan Membaca Pemahaman Melalui Penggunaan Metode Cooperatif Integrated Reading Composition (CIRC) Bagi Siswa Kelas V SD Negeri Temanggal, Kalasan Tahun Pelajaran 2013/2014 . Skripsi. Yogyakarta: Universitas Negeri Yogyakarta

Khalid, Idham. 16 Oktober 2016. Banyak Siswa Lancar Membaca, Tapi Kurang Memahami Bacaannya, Begini Solusinya. (Online), www.inspiramakassar.com/banyak-siswa -lancar-membaca-tapikurang-memahami-bacaannya-begini-solusinya/ (diakses 7 April 2017)

Kurniawan, Komang Indra, Sang Ayu Putu Sriasih, I Gede Nurjaya. 2017. Implementasi Program Gerakan Literasi Sekolah (GIS) Di SMA Negeri 1 Singaraja. e-Journal Jurusan Pendidikan Bahasa dan Sastra Indonesia Volume: 7 No: 2.

Kurniawati, Yati. 2016. Upaya Mewujudkan Sekolah Melek Literasi Melalui Gelis Batuk. Karya Ilmiah. Diajukan untuk Mengikuti Simposium Guru dan Tenaga Kependidikan. Jawa Tengah: 18 November 2016

Mardianti, Selfi. 2015. Peningkatan Keterampilan Menyimak Cerita Pendek Menggunakan Media VCD Film Kartun Pada Siswa Kelas V SD Negeri 1 Pegandekan. Skripsi. Yogyakarta: Universitas Negeri Yogyakarta 
Nurcahyo, Doni Eko. 2014. Peningkatan Kemampuan Menyimak Cerita Menggunakan Quantum Teaching Di Kelas V SD Negeri 1 Iroyudan Padangaran Bantul. Skripsi. Yogyakarta: Universitas Negeri Yogyakarta.

Novitasari, Ni Kadek Ni Ketut Suarni, Ni Wayan Rati. 2017. Pengaruh Model Pembelajaran Siklus Belajar 5e Bermuatan Gerakan Literasi Sekolah Terhadap Hasil Belajar IPA. e-Journal PGSD Universitas Pendidikan Ganesha Mimbar PGSD Vol: 5 No: 2

PISA 2012 Results in Focus What 15-Year-Olds Know and What They Can Do With What They Know. (Online), www.oecd.org/pisa/keyfindings/pisa-2012-results-overview.pdf ， (diakses 7 Februari 2017).

PISA 2015 Results in Focus. (Online), www.oecd.org/pisa/pisa-2015-results-in-focus.pdf, (diakses 5 April 2017).

Rahim, Farida. 2011. Pengajaran Membaca Di Sekolah Dasar. Jakarta: PT Bumi Aksara.

Saddhono, Kundharu \& St. Y. Slamet. 2012. Meningkatkan Keterampilan Berbahasa Indonesia. Bandung: Karya Putra Darwati.

Sinring, Abdullah, dkk. 2016. Panduan Penulisan Skripsi (Proposal Skripsi, Skripsi, \& Karya Ilmiah). Makassar: Fakultas Ilmu Pendidikan Universitas Negeri Makassar.

Somadayo, Samsu. 2011. Strategi dan Teknik Pembelajaran Membaca. Yogyakarta: Graha Ilmu.

Sugiyono. 2016. Metode Penelitian Pendidikan (Pendekatan Kuantitatif, Kualitatif, dan R\&D) Edisi ke-24. Bandung: Alfabeta.

Sukardi. 2013. Metodologi Penelitian Pendidikan Kompetensi dan Praktiknya. Jakarta: PT. Bumi Aksara.

Tarigan, Hery Guntur. 2015. Membaca sebagai suatu keterampilan berbahasa. Bandung: CV. Angkasa.

Undang-Undang Republik Indonesia Nomor 23 Tahun 2015 Tentang Penumbuhan Budi Pekerti. Jakarta: Permendikbud.

USAID Prioritas. 2014. Pembelajaran Literasi Kelas Awal di LPTK. Modul. Jakarta: USAID Prioritas bekerjasama dengan Kementerian Pendidikan dan Kebudayaan.

2014. Praktik Yang Baik di Sekolah Dasar dan Madrasah Ibtidayah (SD/MI). Modul. Jakarta: USAID Prioritas bekerjasama dengan Kementerian Pendidikan dan Kebudayaan.

--. 2015. Pembelajaran Literasi di Sekolah Dasar/Madrasah Ibtidayah. Modul. Jakarta: USAID Prioritas bekerjasama dengan Kementerian Pendidikan dan Kebudayaan.

2015. Praktik yang Baik Budaya Baca di SD/MI dan SMP/MTs. Modul. Jakarta: USAID Prioritas bekerjasama dengan Kementerian Pendidikan dan Kebudayaan.

Wiedarti, P, Laksono, K, Retnaningdyah, P, Dewayani, S, Muldian, W, Sufyadi, S, Roosaria, D. R, Faizah, D. U, Sulastri, Rahmawan, N, Rahayu, E. S, Yusuf, R. A, Antoro, B. 2016. Desain Induk Gerakan Literasi Sekolah. Jakarta: Direktorat Jenderal Pendidikan Dasar dan Menengah Kementerian Pendidikan dan Kebudayaan.

Wulandari, Ranti. 2017. Implementasi Kebijakan Gerakan Literasi Sekolah di Sekolah Dasar Islam Terpadu Lukman Al Hakim Internasional. Skripsi. Yogyakarta: Universitas Negeri Yogyakarta.

Yonantin, Vuri Putri. 2014. Peningkatan Kemampuan Membaca Pemahaman Siswa Kelas III SD Negeri Congkrang II Muntilan Melalui Metode Cooperative Intergrated Reading Composition (CIRC). Skripsi. Yogyakarta: Universitas Negeri Yogyakarta. 